THE INTERNATIONAL

REVIEW OF RESEARCH IN

OPEN AND DISTANCE LEARNING

\title{
The Development of Distance Education in the Russian Federation and the Former Soviet Union
}
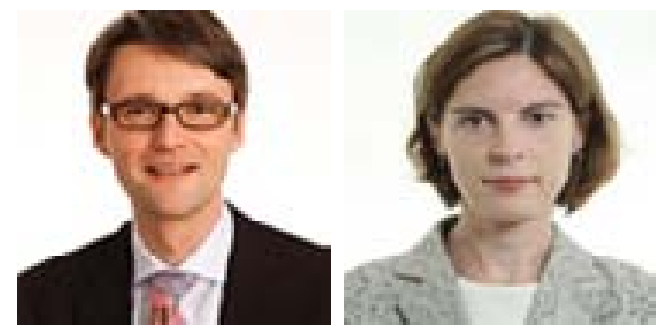

Olaf Zawacki-Richter

Carl von Ossietzky University of Oldenburg, Germany Anna Kourotchkina

St. Petersburg State University of Economics and Finance, Russian Federation

\section{Abstract}

Distance education in the present Russian Federation and former Soviet Union has a long tradition that prevails to this day. The majority of students in Russia are enrolled in distance learning programs. The numbers indicate the existence of a well-established system for distance education, of which little is known in Western literature. A review of distance education research in the Anglo-American sphere showed that within the past 10 years not a single article dealing with the Russian system was published. Consequently, within international DE research Russia remains uncharted territory. The following explorative study introduces the educational and tertiary educational system and presents current statistical data while emphasizing the historical perspective to further describe how the distance education system is embedded therein. In order to discuss current practice in this field, one of the biggest higher distance education institutions in Moscow with approximately 110,000 students is used as an example.

Keywords: Distance education; history; Russia 


\section{Introduction}

The Russian Federation has developed an elaborate distance education system with a long tradition dating back to the October Revolution. More than half of the total number of approximately 7.4 million enrolled students is registered in distance education programs. The history of the Russian higher education system is characterized by an enormous structural change, which has been procured by ideological ambitions directed towards the qualification of citizens who enjoyed only little access to higher education, yet at the same time it has led to problems regarding the quality of educational opportunities within distance education. Today universities invest in the development of modern online distance education, allowing for flexible study, independent of time and place.

Throughout the Western world, particularly among Anglo-American and European scientists, only little is known about this system. One reason might be the language barrier; Russian scientists rarely publish papers written in English and thus remain internationally isolated. A bibliographical analysis of 695 articles published between 2000 and 2008 in five leading journals of e-learning and distance education research confirms that not a single article originated from Russia (Zawacki-Richter, Bäcker, \& Vogt, 2009).

This article aims at shedding light on the Russian higher education system in general and the distance education system in particular. The first part of this paper deals with the historical development of distance education in Russia and provides some background knowledge. The second part then explores the Russian higher education system, focusing on its particular structures, including the different forms of higher education institutions and modes of study in reference to current statistics.

In order to assess the different forms of study, the different types of distance education, the regulatory framework, and higher education statistics as well as various databases of the Russian government were analyzed in addition to internet-based research. Further information predicates on interviews, which have been conducted throughout the summer of 2010 at a large distance education institution counting more than 110,000 students: The Moscow State University for Economics, Statistics and Informatics in Moscow (MESI, МЭСИ). Selected results from the case study of MESI were used to illustrate the structure of the Russian higher education system and its current practices regarding distance education services. Following thorough research on the leading Russian distance education institutions, which possess a long tradition in distance education and e-learning and thus also become internationally visible, MESI was selected as an example for good practice in this field.

MESI was founded in 1932 and is a member of the European Association of Distance Teaching Universities (EADTU). MESI further represents Russia in the European Foundation for Quality in E-Learning (EFQUEL) and holds international importance as it is interconnected with universities in France, Italy, and the Netherlands via double-degree-programs. MESI also publishes one of the leading journals of e-learning and distance education research in Russia. In the ranking of Russia's best business schools, MESI takes $5^{\text {th }}$ place. 
With the introduction of internet-based learning and teaching in 1992, MESI was one of the first to do so. Today MESI counts a total of 109,700 registered students, of which 9,200 are face-to-face students studying at the campus in Moscow. The average age of the students is $24 ; 63 \%$ of the students are female and $47 \%$ are male (October, 2010). Although its headquarters is located in Moscow, MESI operates another 37 regional centres and branches at higher education institutions all over Russia, which can be compared to the system of study centres/regional centres at other distance universities, such as the FernUniversität Hagen in Hagen or the British Open University in Milton Keynes.

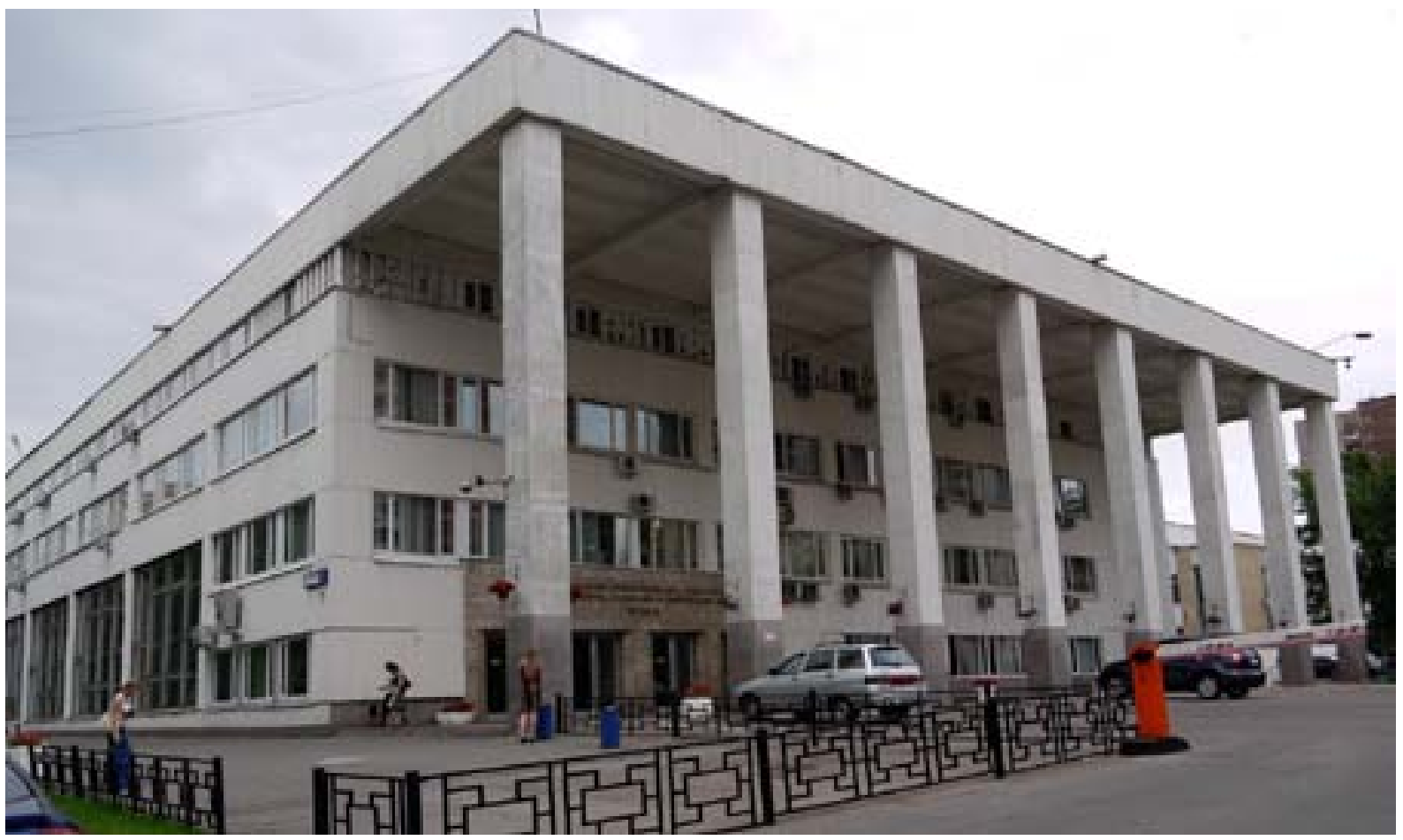

Figure 1. Main entrance of MESI at the campus in Moscow (Source: private photograph, June, 2010).

\section{The Historical Development of Distance Education in Russia}

Adult education in Russia began between the 40s and 60s of the 19th century with the foundation of "Literacy Committees" as well as with the development of Sunday-schools and the Zemstvo (Земство) schools for adults in rural areas around 1860. According to the Soviet Encyclopaedia (1967-78) approximately 27,500 Zemstvo schools had been established in Russia by 1911.

Similar to the development of the so-called correspondence schools for instruction by letter in Germany (e.g., established by Gustav Langenscheidt, cf. Zawacki-Richter, 2011), it was private institutions that predominantly initiated the development of the first print-based distance classes in Russia throughout the second half of the 19th century (e.g., by the So- 
ciety for the Advancement of Technical Sciences and the Society of Community Colleges). Many evening schools ("evening education") were founded around the same time (Rosen, Gardner, \& Keppel, 1965, p. 3).

During Soviet times, the correspondence and evening schools were incorporated into the public educational system and expanded nationwide. Shortly after the October Revolution, the Communist Party demanded in its manifesto from 1919 financial support from the government to promote the "self-education and self-development" of workers and peasants, following its ideological ambitions to elevate the educational standards of the proletariat. Three years later in 1922, a government committee for the advancement of self-education was established, which was also responsible for organizing a nationwide correspondence education system.

Various educational institutions for self-education were established thereafter, including the "Labour Faculty" (рабочий факультет, abbreviated as Рабфак - Rabfak), in which workers and peasants ages 16 and up were prepared for higher education studies:

[...] hundreds of Rabfaks enrolled several hundred thousand adults. Rabfaks were preparatory faculties or departments, located in higher educational institutions, providing accelerated day, evening, and correspondence courses for workers and peasants lacking sufficient learning to benefit from higher education. (Rosen, Gardner, \& Keppel, 1965, p.4)

These higher education opportunities can be regarded as a preliminary stage of distance education. As full-time study the schooling lasted three years; part-time or evening students studied four years. The participants received a national stipend and their study time was partly credited for the hours they worked in the company. During the academic year of 1925-26, 40\% of all freshmen were graduates from Rabfaks (Soviet Encyclopaedia, 196778). However, with the development of the general education system during the 1930s the Rabfaks were quickly dissolved (cf. Egorov, Vendrovsky, \& Nikandrow, 2000).

In 1924, several broadcast universities for workers and peasants were established. The courses were broadcast via radio (e.g., in science of education, social sciences, engineering, radio technologies, agricultural sciences) and contained lessons ranging from 20 to 30 hours. After the students had listened to the lessons, they could participate in a written examination, which had to be turned in to the broadcast university for grading. However, the educational standards did not reach those of regular universities. Consequently, the broadcast universities never became part of the officially accredited educational system.

The development of print-based distance education (correspondence education) as a regular part of higher education began in the 1920s:

Substantial, large scale development in Soviet distance 
education has taken place since a decree of the USSR. In August 1926, the Councils of People's Commissars made correspondence education a regular part of the higher education system. In 1927, a Central Institute for Correspondence Education was established and correspondence preparatory departments prepared young people for entering Communist universities. (Rosen, Gardner, \& Keppel, 1965, p. 6)

The five-year-plans for the economic development of the USSR, which started in 1926, demanded a high number of qualified specialists, which the common education system failed to "produce." Therefore, the correspondence study opportunities were greatly expanded. With the beginning of the 1930s, a network of correspondence education institutions and technical schools (professional schools) was established, particularly with regard to heavy industry workers and their education on factory sites.

While prior to 1929, distance education programs had been designed as mere self-study courses, in which the students had only little or irregular contact with teachers, the development of distance education in the following years was characterized by alternating distance and presence phases, which can be compared to today's format of blended learning. Nickolas de Witt, member of the Russian Research Centre at Harvard University, described the system of the different study forms as follows:

The three basic types of instruction programs offered by Soviet higher educational establishments are: regular day, or full-time study; part-time evening; and part-time extension-correspondence programs. Attempts to equate these programs with particular institutes produce a good deal of confusion. (de Witt, 1961, p. 229)

In addition to that, a fourth form, the so-called "Externat" was established, in which students are not obligated to attend the university at all; instead, they "merely" have to pass the final exams. In 1951, the Externat was abrogated, only to be reintroduced shortly thereafter. The structure of these various study modes has essentially remained the same to this day.

Between 1940 and 1959, the number of part-time students enrolled in distance education courses increased by 4.5 times, while the number of on-campus students doubled. More than half of all students studied part time: "In the fall of 1960, of the total 2,396,00o higher education students, $1,240,000$, or $51.7 \%$, were enrolled in evening or extension-correspondence programs" (de Witt, 1961, p. 231). In 1959, article 121 of the Russian constitution was changed and the new version emphasized the right of the Russian population to education. In order to secure that right, evening and distance education courses had to be further developed.

Against the background of these developments, Otto Peters, founding president of the Fer- 
nUniversität in Hagen, Germany, presented a study in 1967, dealing with "Distance Education at Higher Education Institutions in the Soviet Union." He declares that "the high percentage of distance education students allows for the conclusion that higher education in the Soviet Union underwent structural changes, which are unprecedented in the history of higher education" (Peters, 1967, p. 9).

Unfortunately, the enormous expansion of distance education proceeded at the expense of its quality: "In their resolution from September 10th, 1966, the CPSU central committee and the USSR's Council of Ministers listed the distance education system among problems, which have been solved insufficiently so far" (Peters, 1967, p.11). Despite the efforts to prevent distance education institutions from becoming second-class schools (e.g., equal appointments to professorships), the general problem of lacking quality within distance education could not be solved. The OECD report (1999) Tertiary Education and Research in the Russian Federation criticizes the suitability of the study material for self-study: "There is little evidence of any kind of instructional design and, in some cases, the material provided is barely readable because of poor quality reproduction" (p. 76). It is further stated: "Much of the material as it stands does not really enable independent study by the student" (p.79).

Due to the development of online education, many higher education institutions distance themselves from traditional correspondence studies and invest in modern distance education. The following section illustrates these latest developments in more detail after the Russian higher education system is described in general.

\section{Higher Education in the Russian Federation}

\section{Organization of the Educational System}

The educational system of the Russian Federation is divided into four segments: ${ }^{1}$

- preschool education (дошкольное образование);

- general education (общее образование);

- professional education (профессиональное образование); and

- continuing education (дополнительное образование).

1 ФЗ «Об образовании» №3266-1. от 10.07.1992 (с изм. 1993, 1996, 1997, 2000, 2001, 2002, 2003, 2004, 2006, 2007, 2008) [Federal Law “On Education” No. 3266-1 of July 10, 1992]. http://mon.gov.ru/dok/ fz/obr/3986/ (Retrieved Feb. 25, 2011) 
Higher education falls into line with the branch of professional education, which is structured as follows:

- primary/beginning professional education (начальное профессиональное образование);

- mid-level professional education (среднее профессиональное образование);

- higher professional education (высшее профессиональное образование); and

- postgraduate professional education (послевузовское профессиональное образование).

The primary professional education corresponds with the vocational education on level $3 \mathrm{~B}$ as defined by the ISCED (International Standard Classification of Education) of UNESCO. The mid-level professional education is classified as mixed secondary and tertiary education, which can also include practice-related study courses at academies and institutions (level ${ }_{3} \mathrm{~B}$ through ${ }_{5} \mathrm{~B}$ ).

The higher professional education equals tertiary higher education below the doctorate (level $5 \mathrm{~A}$ ), and the postgraduate professional education equals tertiary education as a research qualification (doctorate, habilitation; level 6).

Upon completion of a two-year upper school (level 3A), students receive university entrance qualification after passing the national examination (EGE) (ЕГЭ - единый государственный экзамен), the general national examination which is since 2009 counted at the same time as the final examination for middle schools and as the entrance examination for higher education institutions in the whole of Russia, the mid-level (full) general education (среднее (полное) общее образование). The university entrance qualification can alternatively be received upon completion of the mid-level professional education (level 5B). In the latter case, students study fewer semesters if they enrol in comparable study courses.

Like many other countries Russia joined the Bologna Accord and has started to adapt to bachelor and master degrees ${ }^{2}$. However, some fields of study, especially the natural, technical, and medical sciences maintained the traditional diploma study courses. Within humanities, similar transitional regulations apply and at some universities students still enrol in traditional diploma study courses. Students also have the possibility to receive an "incomplete higher education" (неполное высшее образование) degree after a minimum of two years of study.

2 ФЗ «О высшем и послевузовском профессиональном образовании» №125 от 22.08 .1996 (с изм. 2000, 2001, 2002, 2003, 2004, 2005, 2006, 2007, 2008). [Federal Law “On higher and postgraduate professional education’]. http://mon.gov.ru/dok/fz/obr/3993/ (Retrieved Jan. 24, 2011) 
For the past 20 years, the Russian higher education system has undergone continuous reformation, which is reflected in the way new forms of higher education have been developed.

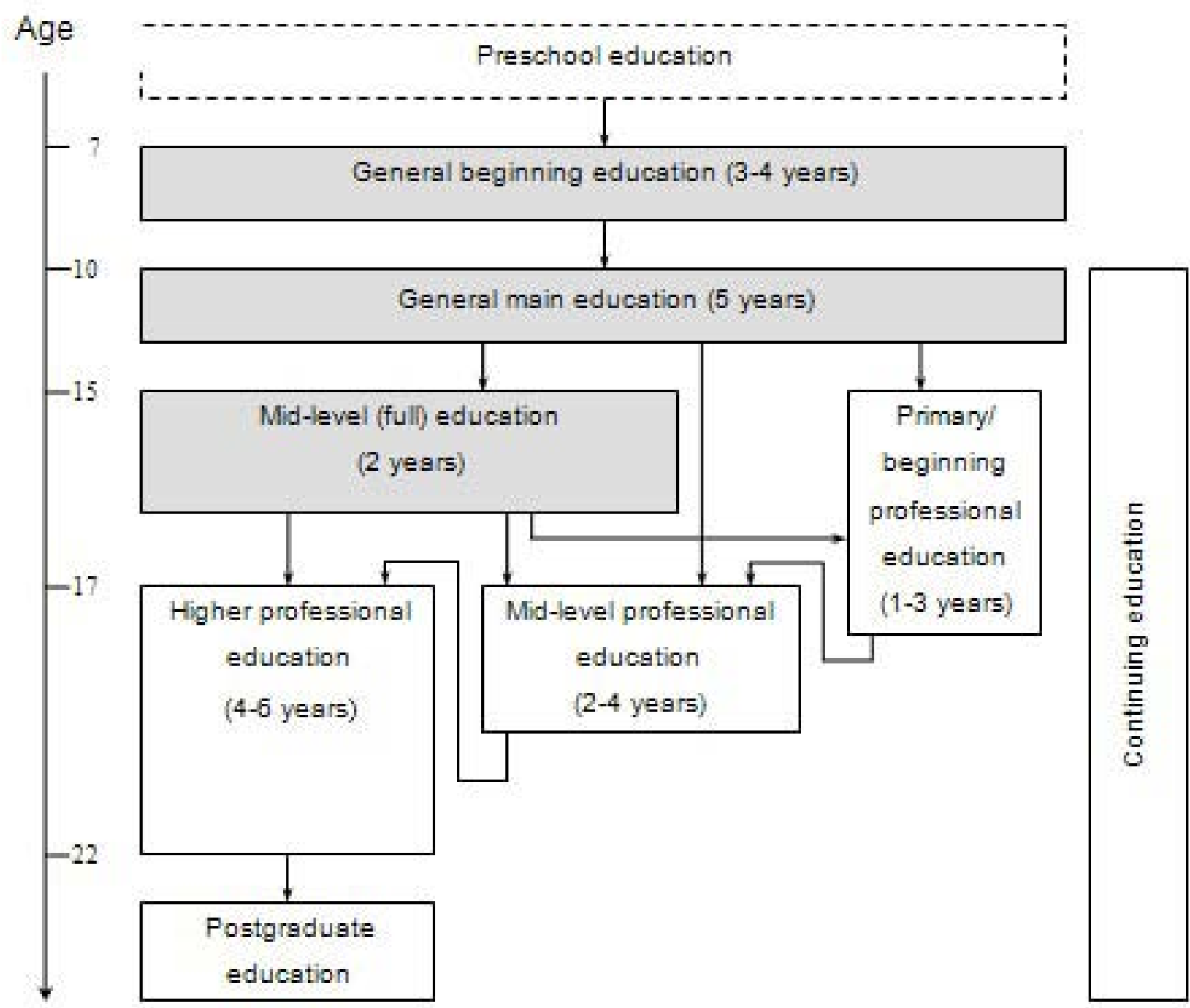

Figure 2. Structure of the Russian higher education system.

\section{Forms of Higher Education Institutions}

In conformity with higher school laws, the following forms exist: National research institutions with special status, universities, academies, and institutes.

\section{National research universities/institutions with special status.}

In 2009, the Lomonosov State University Moscow and the State University St. Petersburg were granted special status as elite-universities. ${ }^{3}$ Such a nomination entails that the nomination of the presidents for these universities is reserved for the president of the Russian Federation alone. Also, the universities organize their study programs independently and

3 ФЗ «О Московском государственном университете им. М.В. Ломоносова и Санкт-Петербургском государственном университете» №259. от 10.11.09 [Federal Law “On Lomonosov State University Moscow and State University St. Petersburg“ No. 259 of Nov. 10, 2009]. http://mon.gov.ru/dok/fz/obr/6368/ (Retrieved Jan. 3, 2011) 
they are exempt from obligatory educational standards that otherwise apply. They are further authorized to conduct entry examinations in order to select their students.

In 2008, an additional status of higher education was introduced: the national research university. ${ }^{4}$ This status can be awarded for a time period of 5 years (extensions are possible) to national universities that are particularly committed to intense research and innovation. The election is based on a contest in which all national universities can compete. The selected universities then receive special financial support (approximately 1.8 billion RUB/45 million EUR for the time period 2009-2013) for the realization of their projects. In the first two rounds of the competition (2009 and 2010), 29 universities were awarded the status of national research universities among them,

- Novosibirsk State University (Новосибирский государственный университет);

- National Research Tomsk Polytechnic University(Национальный исследовательский Томский политехнический университет);

- National Research University St. Petersburg State Polytechnical University (Национальный исследовательский университет Санкт-Петербургский государственный политехнический университет); and

- National Research University N.I. Lobachevsky State University Nizhniy Novgorod (Национальный исследовательский университет Нижегородский государственный университет им. Н.И. Лобачевского).

\section{Federal universities.}

The program for the formation of federal universities in "remote territories" began in 2006. ${ }^{5}$ In 2007, the first two federal universities were established: The Southern Federal University in Rostov-on-Don and the Siberian Federal University in Krasnojarsk (in both cases, three or four regional higher education institutions merged in order to form the new universities). The main purpose of the federal universities is to provide innovative and international study programs and to optimize the transfer of knowledge within the region (the university as a center for innovation). Each federal university thus concentrates on five to six specific fields of research and instruction, which contribute most to the development of the particular region they are located in. The new universities aspire to achieve a place among Russia's top ten higher education institutions and anticipate a place among the 100 best universities worldwide by $2020 .^{6}$

4 Сайт Министерства образования и науки РФ. проект «национальные исследовательские университеты» [Ministry of Education and Science of the Russian Federation, Project «National Research Universities»]. http://mon.gov.ru/pro/niu/ (Retrieved Jan. 3, 2011)

5 Сайт Министерства образования и науки РФ. национальный проект «Образование»/ федеральные университеты [Ministry of Education and Science of the Russian Federation National Project “Education,” Federal Universities]. http://mon.gov.ru/pro/pnpo/fed/ (Retrieved Jan. 3, 2011)

6 Сайт Министерства образования и науки РФ. национальный проект «Образование»/ 
Federal universities as of 2010 are

- Southern Federal University, Rostov-on-Don (2006)/Южный федеральный университет;

- Siberian Federal University, Krasnoyarsk (2006)/Сибирский федеральный университет;

- M.V. Lomonosov Northern (Arctic) Federal University, Arkhangelsk (2009)/Северный (Арктический) федеральный университет им. М.В. Ломоносова;

- Kazan (Volga) Federal University (2009)/Казанский (Приволжский) федеральный университет;

- B.N. Yeltsin Ural Federal University, Ekaternburg (2009)/Уральский федеральный университет им. первого президента России Б.Н. Ельцина;

- Far Eastern Federal University, Vladivostok (2009)/Дальневосточный федеральный университет;

- K.M. Ammosov North Eastern Federal University, Yakutsk (2009)/Северо-Восточный федеральный университет им. К.М. Аммосова; and

- Kant Baltic Federal University, Kaliningrad (2010)/Балтийский федеральный университет им. И. Канта.

\section{Academies and institutes.}

These forms of higher education offer studies and continuing education courses in a specific professional field (e.g., academies for art or architecture, institutes for foreign languages etc.).

\section{Modes of Study}

The current modes of study within the Russian Federation are statutory regulated and divided into four forms.

- On-campus/contact study (очное обучение): Students attend mandatory face-to-face seminars, usually 27-36 hours a week; the maximum workload does not exceed 54 hours a week (including face-to-face seminars, independent study, papers etc.).

- Evening study (очно-заочное обучение): combination of face-to-face and distance study; students attend evening classes (after $6.00 \mathrm{pm}$ ) at the university three or four times a week, usually 16 hours a week. 
- Correspondence study (заочное обучение): independent study including face-to-face study periods. Over the course of the academic year the students attend a face-to-face period (max. 200 hours), which is usually divided into two periods. Evening and correspondence students can prolong the standard period of study for one year.

- Externat (экстернат): independent study. The students independently control their learning process and the period of study. They merely take examinations at the universities.

The different Russian definitions of the concept of distance education and its various forms complicate the methodological discussion at this point since they do not transfer to the definitions that dominate the German or Anglo-American literature.

Rosen, Gardner, and Keppel (1965) use the term part-time education as a broader term to describe extra occupational qualification, continuing education, adult education, and distance education in Russia and the USSR.

Part-time education in the Soviet Union encompasses general education and specialized training of urban and rural youth and adults, 'without interruption of production'. The term, 'part-time education', as applied to the Soviet system may be related to educational programs in the United States known as work-study programs. continuing education, evening correspondence, and parttime study. (p. I)

Within the Russian context, the term distance education (дистанционное образование) is used to describe the modern version of distance education which employs new information and communication technologies (cf. e-learning, blended learning, flexible learning); whereas, the term correspondence education represents the traditional Soviet system of distance education and carries a rather negative connotation. For instance, the State University St. Petersburg presidency classified correspondence education as an obsolete form of lower quality education. Thus, beginning with the academic year of 2010-2011, correspondence education courses will cease to be offered while distance education is planned to further expand. 


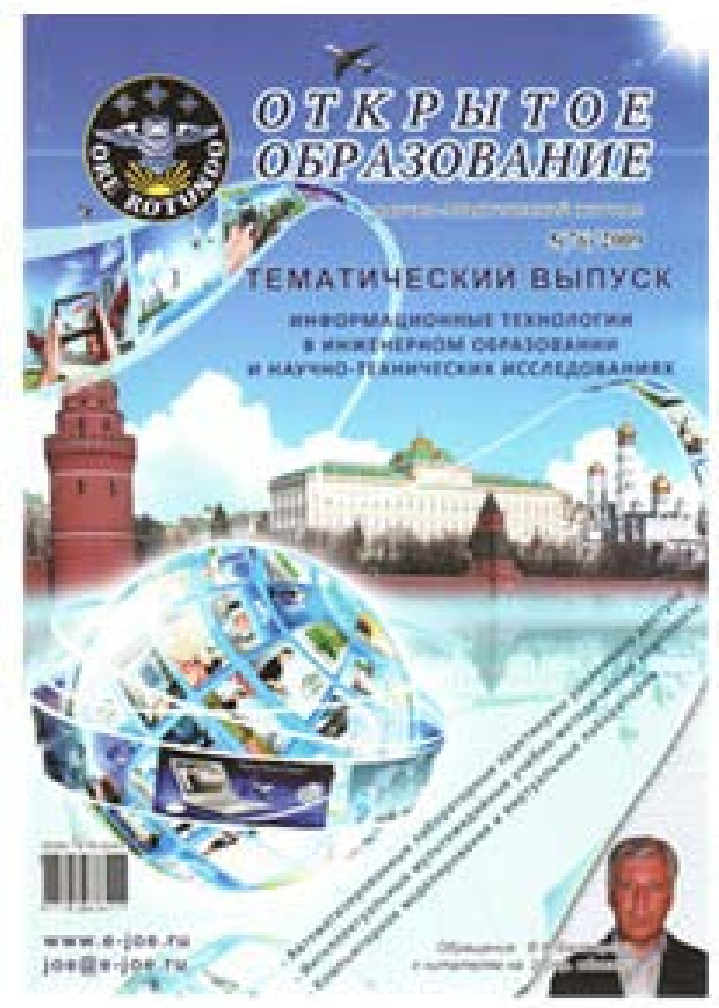

Figure 3. Journal cover of Open Education (2009).

Within the Russian literature the term distance education is similarly discussed but conceptually isolated from the older term correspondence education (cf. Ovsyannikov \& Gustyr, 2001). This distinction is for example adopted by the Russian journal Open Education (Открытое образование), which can be regarded as equivalent to the prominent British journal Open Learning, yet the Russian version employs a greater focus on technological aspects of online distance education. Open Education was first released in 2002 and is published by MESI.

\section{Excursus: E-learning - "modern" distance education at MESI.}

When it comes to introducing new media for teaching and learning, the university MESI takes on a pioneering role among Russia's higher education institutions. As early as 1992, MESI established computer-based learning programs and computer-mediated communication. Today, MESI is equipped with an exemplary educational technology infrastructure (learning and campus management systems), which can even be accessed via mobile devices. MESI further established a virtual library, providing various literature and study material. In order to support the teaching and learning processes, the full range of modern media is employed, varying between print-based asynchronous communication and support of students in online conferences using social software (Web 2.0 tools like wikis or blogs), lectures that are broadcast to the 37 regional centers via video-conference-systems, synchronous virtual classrooms and electronic competence portfolios or complex multimedia learning software. MESI offers a total of 740 online courses (October, 2010), which are either taught completely online or in a blended learning format. 
In order to further promote innovative processes as well as the development, implementation, and effective embedding of e-learning, MESI has invested in respective support infrastructures from the beginning. This institutional e-learning infrastructure involves numerous central service departments and scientific centers: the Department for e-Learning Support and the Research Institute for Knowledge Management, the IT Department, the Institute for Continuing Education, and the Institute for Computer Technologies as well as the Department for Instructional Research. External agencies in Moscow are charged with the development and programming of multimedia applications.

This specific support infrastructure simultaneously serves as a tool for teachers and tutors to design and perform online courses. In addition to that, MESI introduced an incentive system that encourages teachers to use a variety of internet-based communication tools, thus enforcing the participation of tutors in online teaching. Those who pursue the aforementioned teaching methods on a regular basis receive up to $30 \%$ pay improvement. Other bonus programs apply to research and its affiliation with research results in the field of elearning and distance education research, especially with regard to its practical usability in online instruction.

\section{Higher Education Statistics}

In 2006, the Russian Federation invested 3.9\% of its gross national product in its educational system, $0.8 \%$ thereof was invested in the system of tertiary education (OECD, 2009). By way of comparison, the average investment in the educational system within the OECD amounts to $5.3 \%$, the EU 1.9 to $5.4 \%$ and $1.3 \%$ per higher educational branch respectively.

In the academic year of 2009-2010, the Russian Federation included 1,114 higher education institutions, of which 662 were state-owned and 452 independently operated. The first private higher education institutions were founded in accordance to the liberal reform policies at the beginning of the 1990s. Figure 4 shows the development since 1914.

The higher education institutions are spaced out very unevenly throughout Russia. More than a third of all institutions are located in the greater areas of Moscow (264 institutions) and St. Petersburg (82 institutions). A further increase of educational and scientific potential is anticipated by establishing federal universities in neglected regions (see Organization of the Educational System section). 


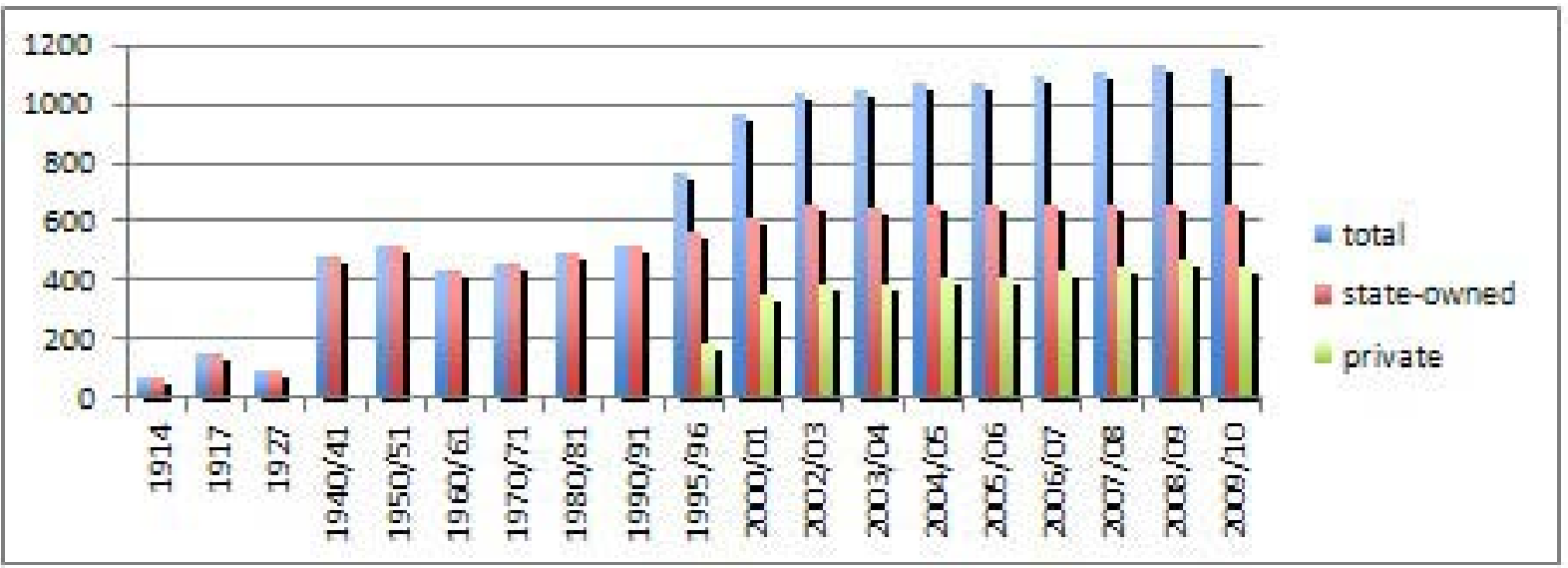

Figure 4. Number of state-owned and independently operated higher education institutions. Source: Федеральная служба государственной статистики [Federal State Statistics Service]. http://www.gks.ru/free_doc/new_site/population/obraz/vp-obr1.htm (Retrieved Jan. 3, 2011)

With regard to higher education, Russia experienced a great expansion over the course of the past 20 years. Compared to 1990-1991, the number of students in Russia more than doubled in 2008-2009, therewith reaching its all-time high of 7.513 million registered students (Table 1); $58 \%$ of all students were female. By 2009-2010 the number of students had slightly decreased to 7.418 million registered students, which may be associated with the demographic developments during the 1990s. Compared to Russia's total population (141.9 million in 2009), 52 out of 1000 citizens were enrolled as students for the winter semester of 2009-2010 (in 1990-91 only 19 out of 1,00o Russians studied even though the total population amounted to 147.7 million in the same year).

All state-owned higher education institutions provide a certain number of state-financed study places. The number of such places is determined annually for each university and may differ greatly depending on the subject studied. Since 2009, the students are selected only on the basis of the EGE. These study places are free of charge and the students receive an additional monthly stipend (approx. 1,100 RUB/28 EUR). At MESI, 38\% of all registered students receive financial support from the government. The national institutions are moreover entitled to offer additional study places in exchange for tuition. The universities decide independently how much tuition is charged, and the specific amount may again differ greatly depending on the subject studied.

Although the independently operated institutions also occupy a considerable section of higher education, few students study there (17\% in 2008-2009). Yet the number of students and families in Russia willing to pay for education continuously increases and in $2009,63 \%$ of all freshmen registered for courses subject to charge. ${ }^{7}$

7 ФЗ «О высшем и послевузовском профессиональном образовании» №125 от 22.08.1996 (с изм. 2000, 2001, 2002, 2003, 2004, 2005, 2006, 2007, 2008). [Federal Law "On higher and postgraduate professional education”]. http://mon.gov.ru/dok/fz/obr/3993/ (Retrieved Feb. 24, 2011) 
Remarkably, the average number of face-to-face students over the past years has moved below 50\% (Table 1). The different forms of distance education have gained currency in both the state-owned and independently operated institutions alike. The number of correspondence students at private institutions is even higher: In 2009-10, 51.3\% of students studying at state-owned institutions and $85.6 \%$ of students studying at private institutions were enrolled in distance education courses.

Table 1

Development of Student Numbers since 1914 According to Modes of Study

\begin{tabular}{|c|c|c|c|c|c|}
\hline Year & Total & $\begin{array}{l}\text { Immediate } \\
\text { study }\end{array}$ & $\begin{array}{l}\text { D i s t a n c e } \\
\text { study }\end{array}$ & $\begin{array}{l}\text { E v e n i n g } \\
\text { study }\end{array}$ & $\begin{array}{l}\text { Exte r n a l } \\
\text { study }\end{array}$ \\
\hline 1914 & 86,5 & 86,5 & - & - & - \\
\hline 1917 & 149,0 & 149,0 & - & - & - \\
\hline 1927 & 114,2 & 114,2 & - & - & - \\
\hline $1940 / 41$ & 478,1 & 335,1 & 128,0 & 15,0 & - \\
\hline $1950 / 51$ & 796,7 & 502,6 & 277,1 & 17,0 & - \\
\hline $1960 / 61$ & $1,496,7$ & 699,2 & 629,9 & 167,6 & - \\
\hline $1970 / 71$ & $2,671,7$ & $1,296,5$ & 985,4 & 389,8 & - \\
\hline $1980 / 81$ & $3,045,7$ & $1,685,6$ & 959,1 & 401,0 & - \\
\hline 1990/91 & $2,824,5$ & $1,647,7$ & 892,3 & 284,5 & - \\
\hline $1995 / 96$ & $2,790,7$ & $1,752,6$ & 855,8 & 174,8 & 7,5 \\
\hline 2000/01 & $4,741,4$ & $2,625,2$ & $1,761,8$ & 302,2 & 52,2 \\
\hline 2002/03 & $5,947,5$ & $3,104,0$ & $2,399,9$ & 346,0 & 97,6 \\
\hline 2003/04 & $6,455,7$ & $3,276,6$ & $2,703,7$ & 351,3 & 124,1 \\
\hline 2004/05 & $6,884,2$ & $3,433,5$ & $2,942,5$ & 361,8 & 146,4 \\
\hline 2005/o6 & $7,064,6$ & $3,508,0$ & $3,032,0$ & 371,2 & 153,4 \\
\hline 2006/o7 & $7,309,8$ & $3,582,1$ & $3,195,9$ & 372,3 & 159,6 \\
\hline $2007 / 08$ & $7,461,3$ & $3,571,3$ & $3,367,9$ & 352,9 & 169,2 \\
\hline 2008/09 & $7,513,1$ & $3,457,2$ & $3,540,7$ & 343,7 & 171,5 \\
\hline 2009/10 & $7,418,8$ & $3,280,0$ & $3,639,2$ & 323,6 & 175,9 \\
\hline
\end{tabular}

Note: Федеральная служба государственной статистики [Federal State Statistics Service]. http://www.gks.ru/free_doc/new_site/population/obraz/vp-obr1.htm (Retrieved Jan. 3, 2011)

The proportion of face-to-face and correspondence students depends greatly on the specific fields of study. Within the academic field of economy and business, fewer students enroll as face-to-face students (36.8\%); whereas, the areas of physics and mathematics (93.0\%), 
weaponry (93.8\%), and information security (94.8\%) count the most face-to-face students.

Table 2

Face-to-Face Student Ratio According to Field of Study in 2007

\begin{tabular}{|c|c|}
\hline Field of study & $\begin{array}{c}\text { Share of pres- } \\
\text { ence students } \\
(\%)\end{array}$ \\
\hline Economics and management & 36.8 \\
\hline Food technology and consumer goods & 44.9 \\
\hline Transport and traffic & 49.6 \\
\hline Human sciences & 50.5 \\
\hline Educational sciences & 52.1 \\
\hline Geology & 52.1 \\
\hline Service management & 55.7 \\
\hline Architecture and construction engineering & $55 \cdot 9$ \\
\hline Social sciences & 56.5 \\
\hline Energy economics and technology, engineering & 58.7 \\
\hline Forestry sciences & 59.1 \\
\hline Agriculture and fishery & 60.6 \\
\hline Metallurgy, material processing & 62.3 \\
\hline Geodesy & 62.6 \\
\hline Chemistry and biology technology & 64.7 \\
\hline Marine engineering & 64.8 \\
\hline Electronic engineering, radio engineering & 65.8 \\
\hline Ecology and disaster control & 67.0 \\
\hline Automatic and control engineering & 67.2 \\
\hline Cultural and art sciences & 67.2 \\
\hline Informatics and IT & 72.4 \\
\hline Aeronautics, aerospace engineering & 75.8 \\
\hline Optics & 79.6 \\
\hline Public health & 81.9 \\
\hline Natural sciences & 82.0 \\
\hline Physics and mathematics & 93.0 \\
\hline Weaponry & 93.8 \\
\hline Information security & 94.8 \\
\hline
\end{tabular}

Source: Образование в России - 2007. Статистический бюллетень. - М.: МГУПИ. 2008. [Education in Russia - 2007, Moscow, 2008]. http://www.ed.gov.ru/edu-stat/ sprav/ (Retrieved Jan. 3, 2011) 
Table 3

Spatial Distribution of Students and the Number of Awarded Degrees According to Modes of Study Offered during 2007

\begin{tabular}{|c|c|c|c|c|c|c|c|c|c|c|}
\hline & RF total & Central FR & $\begin{array}{l}\text { of which } \\
\text { Moscow }\end{array}$ & $\begin{array}{c}\text { North-Western } \\
\text { FR }\end{array}$ & $\begin{array}{l}\text { of which St, } \\
\text { Petersburg }\end{array}$ & $\begin{array}{l}\text { South } \\
\text { FR }\end{array}$ & FR Wolga & FR Ural & $\begin{array}{c}\text { Siberian } \\
\text { FR }\end{array}$ & $\begin{array}{c}\text { Far Eastern } \\
\text { FR }\end{array}$ \\
\hline $\begin{array}{l}\text { Students } \\
\text { total of which: }\end{array}$ & $7,461,310$ & $2,369,518$ & $1,312,642$ & 761,179 & 450,099 & 987,496 & $1,474,848$ & 606,417 & 950,964 & 310,888 \\
\hline Immediate study & $3,571,326$ & $1,033,834$ & 522,931 & 387,992 & 246,370 & 506,273 & 709,110 & 278,515 & 492,901 & 162,701 \\
\hline Evening study & 352,866 & 168,272 & 138,211 & 57,356 & 46,712 & 17,032 & 60,047 & 16,094 & 29,961 & 4,104 \\
\hline Distance study & $3,67,906$ & $1,032,384$ & 521,467 & 305,052 & 146,991 & 452,899 & 700,857 & 311,531 & 423,457 & 141,726 \\
\hline External study & 169,212 & 135,028 & 130,033 & 10,779 & 10,026 & 11,292 & 4,834 & 277 & 4,645 & 2,357 \\
\hline $\begin{array}{l}\text { Degrees awarded } \\
\text { total, of which: }\end{array}$ & $1,335,528$ & 420,569 & 236,466 & 137,247 & 84,333 & 180,095 & 266,434 & 106,609 & 168,466 & 56,108 \\
\hline Immediate study & 643,876 & 189,084 & 95,306 & 68,492 & 43,628 & 95,238 & 129,494 & 46,857 & 86,957 & 27,754 \\
\hline Evening study & 64,261 & 30,200 & 24,384 & 10,271 & 7,935 & 4,036 & 10,817 & 2,785 & 5,209 & 943 \\
\hline Distance study & 604,654 & 183,854 & 99,940 & 56,619 & 30,999 & 78,867 & 125,276 & 56,911 & 75,969 & 27,158 \\
\hline External study & 22,737 & 17,431 & 16,836 & 1,865 & 1,771 & 1,954 & 847 & 56 & 331 & 253 \\
\hline
\end{tabular}

Source: Образование в России - 2007. Статистический бюллетень. - М.: МГУПИ, 2008. [Statistical Report “Education in Russia - 2007”, Moscow, 2008]. http://www.ed.gov.ru/edu-stat/sprav/ (Retrieved Jan. 3, 2011)

$\mathrm{RF}=$ Russian Federation; FR = Federal Region 


\section{Summary and Outlook}

Historically and presently, distance education has played and plays a prominent role in the Russian educational system. Due to the different modes in distance education, a disparate picture is created which is corroborated by the different terminologies used: the traditional correspondence education on the one hand and "the modern distance education" employing new media (e-learning) on the other.

In the Anglo-American sphere, the terms e-learning and distance education are often used synonymously: "The distinction of eLearning from distance education is difficult: In the USA both forms [...] are subsumed under the term Distance Education" (Schulmeister, 2006, p. 5). It is to be observed that in line with the development of internet-based learning and teaching, the originally existing boundaries between distance universities and brick and mortar universities blur. The usage of new media leads to a convergence: Single-mode universities develop into dual-mode universities (Mills \& Tait, 1999). In Russia, this has been the case for a long time. Almost all higher education institutions operate distance departments next to their direct departments.

As was shown in the OECD report (1999), traditional print-based distance education lacked quality. Kruglov (1997) points out that the instructional design is not

laid out for the specific needs of correspondence students and the study materials are often not suitable for selfstudy. Today, universities operating as providers of E-Learning distance themselves deliberately against this distance education of low quality, correspondence education departments are shut down, while new distance education programs are established.

Kruglov (1997) observes that in terms of the development of distance education, that is web-based e-learning, two fundamental points of view are represented in Russia: the technocratic and the system developing. Representatives of the first advocate a radical break with traditional distance education and intend to newly develop modern online distance learning. This point of view is widespread in Russia, which also shows in the technological orientation in the journals. In contrast, representatives of the system developing approach support a further development of distance education.

The Russian government is pushing the implementation and application of e-learning and information and communication technologies (ICT) for teaching and learning in schools and universities by providing project funds for example in the Federal Program for the Advancement of Education 2011-2015 (see http://www.fcpro.ru). The aim of this program is that $85 \%$ of all teachers use ICTs effectively in their classes. Furthermore, various portals that provide access to over 100,000 electronic educational resources have been launched: the Federal Portal "Russian Education" (Федеральный портал «Российской образование“, http://www.edu.ru/db/portal/sites/res_page.htm), the Federal Center 
for Educational Resources (Федеральный центр информационно-образовательных pecyрсов, http://fcior.edu.ru/), and the Russian General Education Portal (Российский общеобразовательный портал, http://www.school.edu.ru/default.asp).

The aim of this paper was an exploration of the Russian distance education system, its historical roots and recent developments in modern distance education and e-learning. By uniting sources that are scattered and already due to linguistic barriers difficult to access, the authors of this article hope to have composed a picture of the Russian educational system with special consideration of distance education.

The example of MESI University in Moscow shows distance education as being an important factor in the development of e-learning. The future needs an understanding of its origins. Looking at the wider picture and directing one's gaze to the East can indeed be fruitful. 


\section{References}

de Witt, N. (1961). Education and professional employment in the U.S.S.R. Boston: Russian Research Center, Harvard University.

Egorov, S., Vendrovsky, R., \& Nikandrov, N. (2000). Russia. In K. Salimova \& N.L. Dodde (Eds.), International handbook on history of education (S. 355-386). Moscow: Orbita-M.

Kruglov, J.G. (1997). Ergebnisse und Perspektiven des pädagogischen Fernstudiums in Rußland. Pädagogische Rundschau, 51, 191-200.

OECD (1999). Tertiary education and research in the Russian Federation. Paris: OECD Publications.

Peters, O. (1967). Das Fernstudium an den Hochschulen der Sowjetunion. Hamburg: Walter Schultz Verlag KG.

Rosen, S.M., Gardner, J.W., \& Keppel, F. (1965). Part-time education in the USSR. U.S. Department of Health Education and Welfare, Office of Education.

Sovietische Enzyklopädie (1967-1978). Große Sovietische Enzyklopädie / Большая Советская Энциклопедия (3. Aufl.). Verlag Sovietische Enzyklopädie.

Zawacki-Richter, O. (2011). Geschichte des Fernunterrichts - Vom brieflichen Unterricht zum gemeinsamen Lernen im Web 2.o. In S. Schön \& Ebner (Hrsg.), L3T - Lehrbuch für Lernen und Lehren mit Technologien. Retrieved from http://13t.tugraz.at/

Zawacki-Richter, O., Bäcker, E.M., \& Vogt. S. (2009). Review of distance education research (2000 to 2008) - analysis of research areas, methods, and authorship patterns. International Review of Research in Open and Distance Learning, 10(6), 21-50.

\section{Athabasca University $\mathbf{A}$}

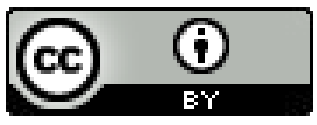

